\title{
Theological Apophaticism and Philosophical Nihilism Towards a Theory of Knowledge ${ }^{1}$
}

\author{
Federico Aguirre \\ Pontificia Universidad Católica de Chile \\ Facultad de Teología, Centro de Estudios de la Religión \\ federico.aguirre@uc.cl
}

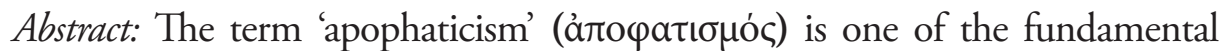
concepts for theological thinking in Christian East nowadays. In fact, it defines a fundamental gnoseological premise that directly affects the way in which thinking progresses in this tradition. In this article, we present the term's interpretation by the contemporary Greek philosopher and theologian Christos Yannaras and the association suggested by this author regarding the contemporary Western philosophical enquiries, in particular regarding 'nihilism'. Yannaras, in his work, drafts an epistemology of the sensorial experience, based on what he

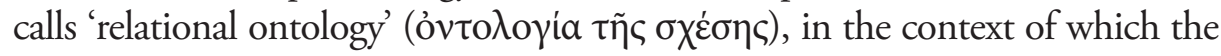
language of art takes on a genuine ontological statute.

Keywords: Apophaticism, Nihilism, Orthodox Theology, Theory of Knowledge, Christos Yannaras.

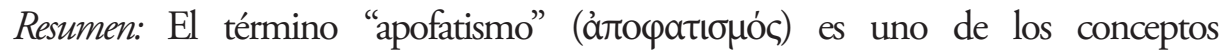
fundamentales del pensamiento cristiano oriental en nuestros días. De hecho, este término define una premisa gnoseológica fundamental para el desarrollo del pensamiento en esta tradición. En este artículo, presentamos la interpretación que Christos Yannaras, teólogo y filósofo griego contemporáneo, hace de dicho término y la relación que establece con la tradición filosófica occidental, en particular con respecto al nihilismo. En su obra, Yannaras plantea una epistemología de la experiencia sensible,

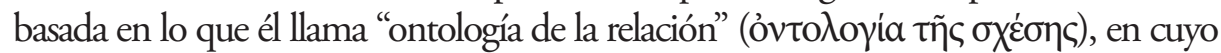
contexto el discurso del arte asume un auténtico estatuto ontológico.

Palabras clave: Apofatismo, nihilismo, Teología ortodoxa, Teoría del conocimiento, Christos Yannaras.

1 The elaboration of this article was supported by the Academic Vicepresidency of the Pontifical Catholic University of Chile. 


\section{INTRODUCTION}

At the beginning of the $20^{\text {th }}$ century, the Eastern Christian tradition is rediscovered and recovers a critical appreciation. Ever since, 'apophaticism'

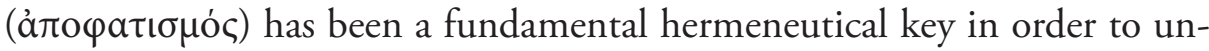
derstand this tradition's particularity. Thus, in Vladimir Lossky's The Mystical Theology of the Eastern Church (1944), a fundamental text for this rediscovering process, apophaticism is presented as one of the Orthodoxy's features that define and differentiate it from the Western philosophical tradition and theology ${ }^{2}$. The main source for Lossky —and for all the literature on apophaticism - is the volume On the Divine Names by the Christian $5^{\text {th }}$-century writer who presents himself as Dionysius the Aeropagite ${ }^{3}$. However, long before Lossky, Dionysius the Aeropagite's text had been commented and disseminated by Maximus the Confessor (580-662) ${ }^{4}$, thus becoming a fundamental reference for the historical evolution of Orthodox theology 5 , On the other hand, in the West, Dionysius the Aeropagite's text would also play a determinant role in the evolution of Scholasticism and, in particular, of the doctrine of the analogia entis, and since the beginning of the $20^{\text {th }}$ century it shall hold a prominent position in contemporary thinking ${ }^{6}$.

In general terms, by 'apophaticism' one usually refers to a 'negative'

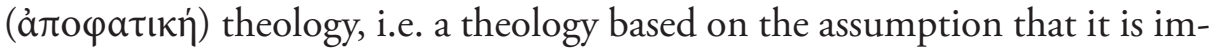
possible to know God and, therefore, refers to the divine being only by negative attributes, such as 'atemporal' or 'immutable'. This theology, also known

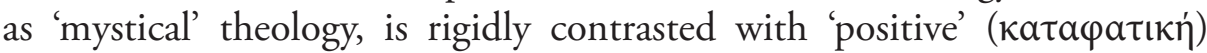
theology. The latter establishes an 'analogical' relationship between God and

2 V. Lossky, The Mystical Theology of the Eastern Church (St. Vladimir's Seminary Press: Crestwood, NY, 1976).

3 De divinis nominibus PG 3, 586-996.

4 Scholia in librum de divinibus nominibus PG 4, 185-416.

5 Сн. Yannaras, On the Absence and Unknowability of God. Heidegger and Areopagite (T\&T Clark: London, 2005) 59.

6 The following works should be mentioned: Byzantinisches Christentum. Drei Heiligenleben (zu Joannes Klimax, Dionysius Areopagita und Symeon dem Styliten) (Munich, 1923), by the writer and painter Hugo Ball, and L'idole et la distance (Paris, 1977), by French philosopher Jean-Luc Marion. For further details on apophaticism in contemporary thinking, vide Z. Yébenes, “¿Salvar el nombre de Dios?: más allá del corpus teológico”, en Tópicos del seminario 22 (2009) 175-204 and A. Bradley, Negative Theology and Modern French Philosophy (Routledge: London, 2004). 
being, whose analogy_analogia entis_could allow man to get to know the nature of God. Hence, 'cataphasis' and 'apophasis' would be the terms of a dialectical relation between God and creation, which would reproduce the dichotomy between matter and spirit, between reason and feelings, between being and nothingness ${ }^{7}$. From the perspective of this interpretation, apophaticism has become the banner of psychological or 'mystical' introspection and the writings of Dionysius the Aeropagite, just another testimony to christianized Neoplatonism ${ }^{8}$.

Nonetheless, the way the Orthodox tradition understands apophaticism differs from the interpretation we have just described, especially with regard to its field of application. In the context of Orthodoxy, apophaticism does not define — not even by negation - a field of knowledge - 'divine' reality-, but it highlights a principally methodological issue, which defines a 'way' of accessing knowledge in general: the absolute priority of experience regarding its formulation. As Lossky points out, apophaticism is 'an existential attitude which involves the whole man: there is no theology apart from experience's. This results in two fundamental differences regarding the definition of apophaticism given in the previous paragraph. Firstly, what defines apophaticism is not attributing 'negativity' to God — which is, in fact, a paroxysm of affirmation - but the relative character of both assertion and negation. Secondly, the interpretation of the notion in question - just like in the case of any testimony to tradition-cannot be lured to an a priori category; on the contrary, it takes on full meaning and validity only from its connection to the other historical testimonies of tradition and, above all, from an 'ecclesiastical' experience that is alive and dynamic ${ }^{10}$. So, in this regard, in S. Janeras' words:

7 The problem of this approach is that assume an ontological link between God and creation, where some created realities as spirit acquire ontological supremacy regard other realities as matter. This 'dialectic' interpretation of apophaticism is introduced, according to Lossky, by Thomas Aquinas (V. Lossky, The Mystical Theology... 26).

8 On the refutation of the Neoplatonic origins of apophaticism, vide V. Lossky, The Mystical Theology... 29-34 and С.. Yannaras, On the Absence... 59-61.

9 V. Lossky, The Mystical Theology... 39.

10 For an overview of apophaticism in the context of contemporary Orthodox theology, vide K. Felmy, Teología ortodoxa actual (Salamanca: Sígueme, 2002) 57-74 and S. JANERAS, "Introducción a la teología ortodoxa", en Las Iglesias Orientales (Madrid: BAC, 2000) 133-254. 
Apophaticism is the way and attitude in which the Orthodox Church considers knowledge of its truth. Apophaticism means rejecting limiting the knowledge of truth to its mere formulation. Its formulation is necessary, as it defines truth, it distinguishes truth from and leads it beyond any distortion. However, this formulation does not constitute nor is it limited to the knowledge of truth, which is always lived experience, a way of life and not a theoretical construct. Apophatic attitude leads Christian theology to using the language of poetry and icons rather than the language of conventional logic and conceptual schematizations, in order to interpret dogmas ${ }^{11}$.

In this regard, it is not by chance that the rediscovering of apophaticism in the context of contemporary philosophy is preceded by the rediscovering of the icon pictorial tradition in the context of modern $\operatorname{art}^{12}$. Within the framework of the bibliographic discussion about apophaticism in the latter half of the $20^{\text {th }}$ century, the work On the Absence and Unknowability of God: Heidegger and the Areopagite, published in 1967 by the renowned Greek philosopher and theologian Christos Yannaras, shall set a precedent, both in the field of contemporary Orthodox theology and in the field of contemporary philosophy ${ }^{13}$. This work, apart from being a contribution to each one of these fields separately, will also build a bridge between them and will set a starting point for the philosophical enquiry of the Greek writer. In this respect, for Yannaras, apophaticism is not limited to being an aspect of the Christian doctrine that would shed light on certain areas of contemporary thinking, but it results in an entire 'gnoseology', from which a concrete understanding of the world, i.e. an 'ontology', derives. According to Yannaras, the importance of this apophatic gnoseology for our era would be based, on the one hand, on the fact of sharing similar methodological assumptions with nihilism and, on the other, on the ontological perspective that derives from it, which would provide a way out of the bottleneck of contemporary nihilism ${ }^{14}$.

11 S. Janeras, “Introducción...”, 198 (our translation).

12 F. J. Хаміsт, "La pregunta hermenéutica por el ícono". Comprendre: Revista Catalana de Filosofía 15/2 (2013) 35-50.

13 For a critical study of Yannaras' work, vide R. D. WiLliams, "The theology of personhood. A study of the thought of Christos Yannaras", Sobornost 6 (1972) 415-430; for a bibliographical review of his work in English, vide A. Louth, "Some recents work by Christos Yannaras in english translation”. Modern Theology, 25: 2 (2009) 329-340.

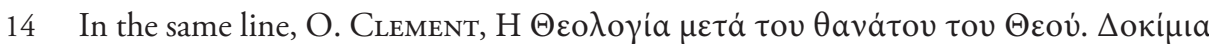

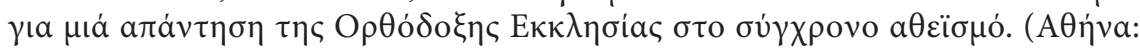




\section{APOPHATICISM AND NIHILISM}

In fact, in the book On the Absence and Unknowability of God: Heidegger and the Areopagite, Yannaras considers nihilism a fundamental prerequisite of apophatic knowledge ${ }^{15}$, an affirmation for which he is censored in certain Orthodox theological circles. However, for the Greek writer, nihilism is at the same time a meeting point — in quality of gnoseology—and a separation point - in quality of ontology—between modern philosophy and current Orthodox thinking. In this respect, on the one hand, nihilism-just like apophaticism—rather than denying, offers a new perspective for metaphysical enquiry but, on the other hand, the results of such an enquiry are completely different.

Following Heidegger, Yannaras supports that nihilism does not constitute a simple negation of the ontological problematic but a lucid confirmation of the failure of the Western metaphysical tradition, a failure exemplarily testified by Nietzsche's work on God's death ${ }^{16}$. For contemporary thinking, in fact, Nietzsche's apotheosic 'God is dead' symbolizes the alleged end of a way of thinking developed mostly in Western Europe, that could be characterized as 'axiological', for the question about the meaning of existence is limited to establishing a 'value' system which organizes the world and governs human behavior ${ }^{17}$. In this context, 'the existence of God is a conceptual necessity, secured by demonstrative argument, but unrelated to historical experience and the existential condition of human beings' ${ }^{18}$. This way of thinking, which is in the core of the Western metaphysical development, could be expressed through the gnoseological dualism of subject-object, a valid equation both for medieval theological thinking (truth as adae-

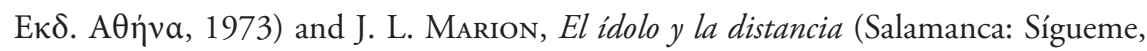
1999).

15 Ch. Yannaras, On the Absence... 49-56.

16 De la gaya ciencia $\$ 125$. Vide CH. Yannaras, On the Absence... 39-47. Nihilism is the name for a historical movement, discerned by Nietzsche, which after dominating the preceding centuries has determined the current one. The interpretation of this movement Nietzsche concentrated into the brief statement: 'God is dead." M. Heidegger, "Nietzsche's Word: 'God is dead", in Off the Beaten Track (Cambridge: Cambridge University Press, 2002) 160.

17 Vide Ch. Yannaras, On the Absence... 17 and J. Ferrater Mora, Diccionario de Filosofía, Tomo I, (B. Aires: Ed. Sudamericana, 1965) 389.

18 Ch. Yannaras, On the Absence... 22. 
quatio intellectus et rei) and for modern scientific thinking (cogito, ergo sum), even if the latter seems to subvert the first one-which it does regarding the 'content' of metaphysics but not regarding the gnoseological model in question ${ }^{19}$.

However, in Nieztsche's affirmation one should not read a simple atheistic outburst. Rather than a reaction to a concrete moral paradigm or a concrete religious tradition, God's death means metaphysics' death in the way it was meant by the Western philosophical tradition ${ }^{20}$, i.e. the disappearance of every reference for human existence and culture progression. Therefore, rather than an actual statement, the phrase 'God is dead' is the confirmation of an absence: where Western philosophical tradition used to place the truth of existence and the coordinates of culture - whether it was God, History, or Science - there is 'nothing'. In this regard and in a strict sense, even atheism fades away as a conviction ${ }^{21}$. The verification of this absence dramatically results in the 'destruction' of the Western metaphysical tradition $^{22}$. Nevertheless, from among the debris of metaphysical constructs, the ontological question still lingers on and questions yet again contemporary man:

it is of decisive importance, first, that we allow space for beings as a whole; second, that we release ourselves into the nothing, that is to say, that we liberate ourselves from those idols everyone has and to which they are wont to go cringing; and finally, that we let the sweep of our suspense take its full course, so that it swings back into the fundamental question of metaphysics that the nothing itself compels: Why are there beings at all, and why not far rather Nothing ${ }^{23}$ ?

According to Heidegger, in order to stay loyal to the nothing's questioning and to avoid immersing once again the question about the being

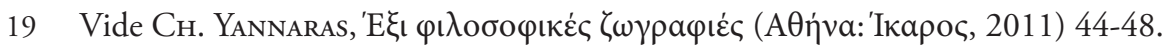

20 M. Heidegger, “Nietzsche's Word...” 163.

21 'If God-as the supersensory ground and as the goal of everything that is real-is dead, if the supersensory world of ideas is bereft of its binding and above all its inspiring and constructive power, then there is nothing left which man can rely on and by which he can orient himself.' (M. Heidegger, “Nietzsche's Word ...” 163).

22 M. Heidegger, Ser y tiempo (Santiago de Chile: Ed. Universitaria, 1998) 43-50.

23 M. Heidegger, "What is Metaphysics?", in Pathmarks (Cambridge: Cambridge University Press, 1999) 96. 
in the oblivion of mere abstract concepts, it is indispensable to distinguish between the 'ontic' level and the 'ontological' level, i.e. between the 'interpretation' (Auslegung) of the being —its explicit formulation through language - and the 'comprehension' (Verstehen) of the being —or 'opening up' to the being that constitutes human existence as such and that is previous to any discursive formulation ${ }^{24}$. In this way, no matter how we may wish to interpret what it is —on the ontic level-, the being shall always remain to a certain point not-interpreted, not-said, not-explicitely formulated-on the ontological level—: therefore, the being, to a certain point, shall always be 'nothing'25. Because, within the framework of the turn given to ontology by Heideggerian nihilism, the being 'loves to conceal itself' (крú $\pi \tau \varepsilon \sigma \theta$ a $\varphi \iota \lambda \varepsilon \tilde{\imath})$ and no longer shows itself plainly as a patent phenomenon but by virtue of its filiation to the nothing as soon as its full existence is 'disclosed' illuminating, but remaining undefined ${ }^{26}$ :

However being may be explained, whether as spirit in the sense of spirituality, as becoming [Werden] and being alive [Leben], as formulation [Vorstellung], as will [Wille], as substance [Substanz], as subject [Subjekt], as energeia, or as the eternal return of the equivalent, be-ing appears as be-ing each time in light of be[ing]. Whenever metaphysics formulates be-ing, it has there shed light on $b e[$ ing]. $B e[$ ing] has arrived with[in] emergence $\left(A \lambda \dot{\eta} \theta \varepsilon\llcorner\alpha)^{27}\right.$.

\section{Eastern Christian Theory of KNOWLedge}

The distinction between the 'ontic' and the 'ontological' level on which Heideggerian ontology is based, points out Yannaras, shall liberate the ontological question of its being subject to the intellectualism

24 Vide M. Heidegger, Ser y tiempo... 32-37 and 172-177, and J. Ferrater Mora, Diccionario... 320. Human existence as Dasein or the 'there' of the being, the 'where' in which it presents itself is, according to Heidegger, the condition of possibility of the question about the being.

25 'The nothing does not merely serve as the counterconcept of beings; rather, it originally belongs to their essential unfolding as such.' M. HeIdegger, "What is Metaphysics..." 91.

26 Vide Ch. Yannaras, On the Absence... 53-54.

27 M. Heidegger, "What is..." 66. Heidegger refers here the ontological difference, i.e. the distinction between being (Das Sein) and beings or entities (Das Seiende). The Being (Das Sein) is shown on entities (Das Seiende), but it do not identify with them. We will revisit this issue later. 


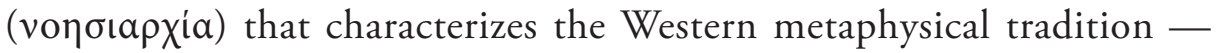
liberate it from its intellectual 'idols' - and, consequently, shall subvert the gnoseological model on which these metaphysics are based. Thus, knowledge and the possibility of its verification do not depend on any $a$ priori determination; on the contrary, it is based - it finds its condition of possibility - on the experience man has of being, on the direct 'dealing with' all that it is ${ }^{28}$. It should be highlighted at this point that the gnoseological priority of an a priori free choice does not mean placing knowledge on the subjective level, but it comes to reveal the structure of priority of understanding as a 'way' of being of humans-Dasein-: before any kind of objectivization, and even the appearance of a subjective 'conscience', the human being already 'understands' being through its direct 'dealing with' or experience of everything that it is and it is precisely this experience what makes it possible, in a later stage, to consider the things of the world as ob-jects ${ }^{29}$.

The subvertion of this gnoseological model shall be consummated by Heidegger through its reelaboration of the traditional concept of 'truth': truth is not the mere coincidence (adaequatio) between a subject's judgment and a completely objectivizable reality, but it constitutes an event characterized by 'disclosing' (крú $\pi \tau \varepsilon \sigma \theta a \iota ~ \varphi \iota \lambda \varepsilon \tilde{)})$. In this event, the being (Das Sein) shows itself in entities (Das Seinde) but, at the same time, remains rooted to the nothing and, therefore, resists to be exhausted in any kind of formulation, even if this formulation is backed by an-ecclesiastical-institution or a-scientific - method $^{30}$. For Yannaras, this kind of nihilism is, thus, the one that underlies apophaticism and the theology deriving from it:

Consequently, nihilism, as the denial of the equation of Being and God (the denial of their subjection to conceptual fabrications) or as the reference of God to nothing (with the concept of indeterminism or of the emptiness that persists in thought when it defines the mode of being) such a nihilism seems more "theological" than rationalist metaphysics or utilitarian ethics ${ }^{31}$.

28 Ch. Yannaras, On the Absence... 83-97.

29 Vide M. Heidegger, Ser y tiempo... 94-99.

30 For the Heideggerian concept of truth, vide M. Heidegger, Ser y tiempo... 233-250.

31 Ch. Yannaras, On the Absence... 54. 
This acknowledgment of the relentless isolation of God and being seems to be the culmination point of the relation between apophaticism and nihilism, and, to some point, the ontological perspective that Yannaras recovers from apophaticism is swept along by the Heideggerian torrent: 'From this point, God's death would make all walls disappear and open the possibility of a new philosophical activity, which would be implicit in the serenity, in the detachment of Gelassenheit, and in the essence of poetry guarded by the poet ${ }^{32}$. In this way, however, the relation between apophaticism and nihilism in the framework of contemporary literature discussion seems to be resolved again in the mere attribution of a 'negative' —or at least 'poetic' — character to every ontological proposition, thus reducing apophaticism to an avant la lettre nihilism ${ }^{33}$.

Nevertheless, as highlighted in this article and also by Yannaras, in the perspective of apophaticism - and also of nihilism, which is its condition of possibility-, not even the recognition of the absence of likeliness of God and being constitutes a determination of its essence ${ }^{34}$. Therefore, according to the Greek author, the question opened by Heideggerian nihilism, the kind of nihilism which is more 'theological' than the Western metaphysical constructs, is not necessarily exhausted in the observation of an 'absence', but it opens a fundamental question for contemporary thinking: is that which is not an object of knowledge and shall never become such simply 'nothing ${ }^{35}$ ? Obviously, any answer to this question could mean going back to intellectualist idolatry of the Western philosophical tradition, a fear which leads Heidegger, according to Yannaras, to the elaboration of an ontology of 'absence'. In other words, God or any other reality that is recognized itself as a causal principle of the existent is literally conspicuous by its absence:

Furthermore, from this perspective Heidegger appears to be justified, when he interprets existence only as dis-closure $(\dot{\alpha}-\lambda \dot{\eta} \theta \varepsilon\llcorner a)$, as nonoblivion ( $\mu \grave{\eta}-\lambda \dot{\eta} \theta \eta)$, as emergence from nothingness (the "other side" of ontic disclosure) into the manifestation of temporality. It is only through the ontology of the Church that nothingness itself does not remain the inexplicable, un-disclosed side of Being, but constitutes the possibility of God's activity or energy outside God, the possibility that

32 Z. Yébenes, “¿Salvar el nombre de Dios?...” 176.

33 Vide Z. Yébenes, “¿Salvar el nombre de Dios?...” 176-177.

34 Сн. Yannaras, On the Absence... 66-67.

35 Сн. Yannaras, On the Absence... 55. 
that is experienced in the dynamism of the mode of the divine personal existence, and shows God as "also the cause of nothingness" 36.

Although the Oriental theological tradition's apophaticism and Heideggerian nihilism coincide in the impossibility of objectivising God and the being, in the context of Christian revelation, if the possibility to know God experientially and positively didn't exist, apophaticism would simply be a 'negative theology', a 'theological agnosticism'37 —in other words, the paroxysm of any intellectual idol ${ }^{38}$. However, for Yannaras, the question posed by Heideggerian nihilism can lead to the affirmation of 'absence', which is expressed by agnosticism, as well as to the affirmation of a 'lack of knowledge' or á $\gamma v \omega \sigma i a$, an affirmation that, however, is in itself a 'positive' experience of $\mathrm{God}^{39}$. As pointed out by Yannaras, in the context of Christian revelation, this experience of God is testified to by the words 'Father', 'Son' and 'Holy Spirit'. These words, nonetheless, in contrast to the word 'Zeus', for instance, do not declare 'what' God is but 'how' he is, they do not define an 'individual essence' but a 'personal way of being'. God is Father because he is Father of the Son, because he freely and eternally acts beyond himself. Thus, what is not known about God is his 'essence', but it is precisely not known through the positive experience of 'how' he is, how he has historically presented himself, and this way of being is the 'relationship' ${ }^{40}$.

At this point, Yannaras shall acknowledge a distancing between Heideggerian nihilism and the Orthodox theological tradition apophaticism: a difference between the 'ontology of absence', which derives

36 С. Yannaras, On the Absence... 80-81.

37 С.. Yannaras, On the Absence... 70.

38 'As long as chains of assessment in terms of value remain, anti-racionalist metaphysics will lead to the extremes of rationalism - and yet anti-metaphysical atheism is more concerned about God than theism itself.' (Сн. Yannaras, On the Absence... 56).

39 'We are absolutely ignorant of what God is, yet we know, through the experience of his natural and historical revelation, the mode in which he exists.' (СH. Yannaras, On the Absence... 78). Vide also V. Lossky, The Mystical Theology... 25.

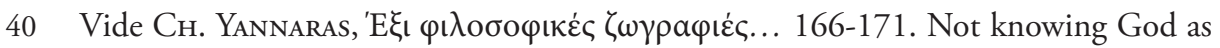
an 'object' is, in a sense, a result of knowing him as a 'relationship', for any relationship presupposes surpassing distance. Although we cannot get into more details on this issue, it should be highlighted that God's incarnation in the historical person of Jesus of Nazareth, who precisely 'incarnates' perfectly the 'relationship' between man's and God's realities, plays a fundamental role in this understanding of divine reality. 
from nihilism, and the apophaticism of the Oriental theological tradition, which derives from a 'relational ontology'. In the first case, the fundamental experience for getting to know the truth of being is the experience of anxiety: 'In the clear night of the nothing of anxiety the original openness of beings as such arises: that they are beings — and not nothing' ${ }^{41}$. In the second case, the 'relation'- 'eros', as Yannaras later on puts it -is the original experience that awards man the knowledge of the participation in - the truth of existence: 'The energies represent the possibility for the imparticipable and incommunicable divine "essence" to offer itself as willing personal communion, a willing that does not remain ineffective, but "calls" and establishes beings, "determines" them in being, and assembles them as a cosmos of harmony and wisdom'42. Therefore, in the perspective of this 'relational ontology', apophaticism shall be defined in the following terms:

No intellectual definition (whether conceptual or verbal) can ever exhaust the knowledge afforded us by the immediacy of relationship, consequently the logical definition of essence (as the common principle of examples of the same form) follows and does not precede the otherness of each existent, which I know in immediate relationship with it. Thus, if God exists, he is primarily known as a person (bypostasis) in the immediacy of relationship, and not primarily as an essence with its conceptual definition. And given the inadequacy of reason to replace or exhaust the cognitive immediacy of relatedness (particularly as regards the hypostasis of the person, where otherness is not simply phenomenological, but the freedom of the subject's self-determination of its mode of existence), we may speak of the apophatic character of any definition that is given of the personal otherness of God $^{43}$.

As Yannaras points out, in the context of this 'relational ontology' which derives from apophaticism, the linguistic expression's function is, rather than the function of a 'concept', the function of an 'image', which, on the one hand, defines, provides a 'scale' for the comprehension of signified reality and, on the other hand, never gets to be identified with it ${ }^{44}$. In this context, the task of the image is not the 'imitation'

41 M. Heidegger, "What is..." 90.

42 Сн. Yannaras, On the Absence... 79.

43 Сн. Yannaras, On the Absence... 29-30.

44 Сн. Yannaras, On the Absence... 75. Vide also V. Losskr, The Mystical Theology... 30-1. 
of a nature predetermined by natural laws nor the 'symbolization' of an abstract content that cannot be represented under the surface, but a starting point for establishing a dynamic 'relationship' with signified reality ${ }^{45}$. Thus, 'beauty' ( $\left.\kappa \dot{\alpha} \lambda \lambda \mathrm{o}\right)$ is the determinant feature of apophatic language, given that its main objective is to summon ( $\alpha \lambda \lambda \tilde{\omega})$, put into relationship ${ }^{46}$.

\section{Conclusions}

The detailed exposition of the 'relational ontology' which, according to Yannaras, derives from the ecclesiastical experience and its link to the Eastern Christian theological tradition exceeds by far the limits of this presenta$\operatorname{tion}^{47}$. The aim of this brief presentation is to underscore the consideration of apophaticism as a methodological prerequisite for the afore-mentioned ontology and to provide an insight of its eventual contribution to contemporary philosophical discussion. In this regard, even if the 'content' of the ontology deriving from apophaticism and the one deriving from nihilism differ, they both share a goal - a methodological suggestion of the ontological question - as well as a fundamental gnoseological prerequisite - the methodological priority of the concrete existence regarding any determination of essence. This priority is shared by apophaticism not only with nihilism but also with 'existentialism', to which, at least in the case of Heidegger, nihilism pertains ${ }^{48}$.

Establishing this methodological —only methodological, not ontological - priority of the 'existence' regarding 'essence', apart from defining a common area for theological and philosophical research in the context of contemporary thinking and providing a fundamental gnoseological role to

45 С. Yannaras, On the Absence... 71. Cf. Heidegger's definition of the work of art, i.e. the art as the happening of truth, in M. Heidegger, Arte y poesía (Buenos Aires: FCE, 1992) 35-41.

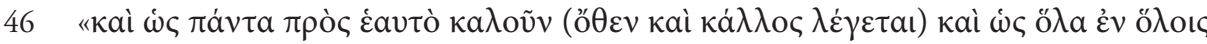

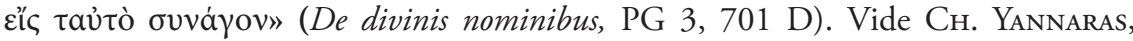

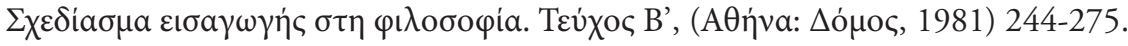

47 This shall be the core of Yannaras' philosophical project, the first elaboration of which can be found in Person and Eros (Athens, 1970), the most famous and diffused work of the Greek author, translated in seven languages. English translation: $\mathrm{CH}_{\text {H }}$ YANNARAs, Person and eros (N. York: Holy Cross Orthodox Press, 2007).

48 In this regard, Kierkegaard's or Sartre's suggestions would also have an apophatic

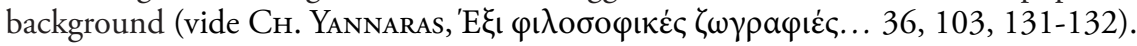


aesthetic experience, subverts the gnoseological model of modern science, a model that determined the evolution of Western civilization, the crisis of which is an irrefutable fact. This priority of 'existence' regarding 'essence' is, in fact, diffused by 'God's death' and is in the basis of the consequent negation of intellectual idols that take the 'place' of God and being, a negation to limit the verifiable content of reality only to 'data' provided throught its objectivization.

Therefore, in the gnoseological perspective shared by apophaticism and nihilism, the access to knowing the truth is not limited to a mere 'intellectual aptitude' but it constitutes a 'mode of being' of human existence, which is characterized, in the case of Heideggerian ontology, by its openness to the comprehension of the being and, in the case of ecclesiastical ontology, by its communion with the personal existence of God. On the other hand, the comprehension of being and personal communion always take place through a fundamental 'affective disposition', which indicates the 'existential' implication of the knowing subject: 'anxiety', in the case of nihilism, and 'eros', in the case of apophaticism ${ }^{49}$. In this regard, the positive knowledge of reality is not guaranteed by the 'distance' between the knowing subject and the known object but, on the contrary, recognizes as its condition of possibility the 'proximity' of the relationship:

Knowledge is not a subjective certification of given ob-jects and "states of affairs" (Sachverhalten). It is a subjective participation in cooperative relationships, it is the congregating fact of relationship [...] Knowledge is a relationship that does not exhaust itself in impressions or information provided by the senses: it takes place in a dynamic, not predetermined way as participation of the observer in the observed, beyond a scientific aspiration, as immediacy of communion of the subject with the existential evolution of reality ${ }^{50}$.

In the context suggested by Yannaras, a more determinant factor than the 'negative' conclusion of Heideggerean philosophy or the 'positive' conclusion of Orthodox theology is the fact that, by transferring the ques-

49 The term 'affective disposition', in the framework of existential analytics of Dasein, refers to the fact that comprehension is always 'tinged' by a particular feeling in which man 'finds' himself, a term which, just like 'understanding', does not refer to a mere faculty of human existence but is its way of being (vide M. HeIdegGer, Ser y tiempo... 158-166).

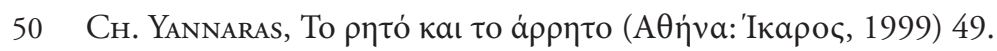


tion about the being form the level of essence to the level of existence, the 'space' where God, sooner or later, can appear, i.e. enter into communion with man, is defined. Otherwise, if the testimony of ecclesiastical experience were limited to a mere affirmation of its positivity and to a restricted delimitation of its 'truth' regarding surrounding reality, it would loose its eminently experiential horizon, its 'apophatic' character, only to become a mere 'dogma'.

Therefore, establishing this methodological relation does not aim neither at a conversion of nihilism nor at an apology of the Orthodoxy, but at setting a framework in which the testimony of the ecclesiastical experience is comprehensible nowadays through a language which is familiar to us. Furthermore, it must be remembered that the Church Fathers used the philosophical language of ancient Greek thinking not because was a sacred or special language, but because was a familiar way of expression in their times, in order to testify the ecclesiastical experience. In this regard, Heidegger's distinction between the 'ontic' and the 'ontological' - between the 'interpretation' and the vital 'comprehension' of the being, which is in the basis of this interpretation- puts us in the threshold of apophaticism by highlighting the absolute priority of the experience before any type of formulation - 'there is no theology apart from experience'. Nevertheless, from the perspective of the 'relational ontology', apophaticism of the ecclesiastical experience seems to be moving a step forward: there is no experience apart from relation. 